\title{
КОМПЛЕКСНА ПЕРЕРОБКА СИРОВИНИ 3 ВИКОРИСТАННЯМ ТЕХНОЛОГІЙ АДРЕСНӦ̈ ДОСТАВКИ ЕНЕРГІЇ У ВИРОБНИЦТВІ ПЕКТИНІВ
}

\author{
Яровий І.І., канд. техн. наук, доцент, Алі В.П., аспірантка \\ Одеська національна академія харчових технологій, м. Одеса
}

Розглянуто можливості використання технологій адресної доставки енергії (АДЕ) в процесах комплексної переробки сировини рослинного походження на прикладі комплексу технологічних процесів характерних для виготовлення пектину. Показано актуальність прочесів отримання пектинових речовин для сучасної промисловості та перспективні напрямки використання пектину. Наведено приклади реалізації технологій виготовлення пектину вітчизняними та зарубіжними виробниками, та приведено наближену оцінку вартості і складності пектинового виробництва.

Як варіант удосконалення та здешевлення технології виготовлення пектину запропоновано використання технологій АДЕ для основних технологічних операцій пектинового виробництва: сущіння пектиновмісної сировини, екстрагування пектиновмісних речовин, випарювання пектиновмісного екстракту. Для процесу сушіння пектиновмісної сировини приведено результати експериментального дослідження кінетики прочесу вологовидалення з оболонок ичитрусових плодів, при використанні комбінованого способу сушіння - мікрохвильового енергопідведення та фільтрачійного відведення вологи. Запропоновано обтрунтування для використання такої комбінації технологій сушіння та вплив механодифузійного ефекту на кінцеву продуктивність вологовидалення зазначеним комбінованим способом сушіння. Описано загальну конструкцію стрічкової, модульної сушильної установки з комбінованим способом сушіння сипкої рослинної сировини.

Надано оиінку результатів отриманих при дослідженні кінетики процесу сушіння пектиновмісної сировини та загального потенціалу технології АДЕ для процесів швидкісного низькотемпературного сушіння термолабільних матеріалів. Запропоновано шлях для впровадження технологій АДЕ на інших технологічних ділянках виготовлення пектину. Зокрема приведено посилання на інноваџійні процеси екстрагування в середовищі електромагнітного поля надвисокої частоти та узагальнено потенціальні переваги та недоліки використання аналогічних технологій у виробництві пектину. Запропоновано використання технології випарювання розчинів у вакуумних випарних апаратах з використанням мікрохвильового енергопідведення для аналогічної технологічної операції при виготовленні пектину.

Ключові слова: пектин, мікрохвилі, електромагнітне поле, екстрагування, випарювання.

Вступ. Виробництво пектину в світовій харчовій індустрії займає далеко не останнє місце і системно зростає. Гелеутворююча здатність пектину робить його постійним компонентом (харчова добавка Е-440) таких харчових продуктів як йогурти, майонез, соуси, кондитерських виробів - желе, мармеладу, цукерок, морозива, зефіру. Важливою областю використання пектину є косметологія та фармацевтика. Відомо про цінність пектину як харчової добавки, що позитивно впливає на кровообіг та систему травлення людського організму, покращує виведення з організму токсинів та важких металів.

Одним 3 нових напрямів широкого використання пектину може стати виготовлення упаковки здатної біологічно розкладатись в зовнішньому середовищі. Технології створення замінників пластикових плівок на основі пектину - $є$ актуальною темою робіт науковців [1].

Актуальність. Попри високу перспективність пектину як компоненту багатьох продуктів, в світі його виробляється небагато, за деякими оцінками фахівців, це менше 50 тис. тон яблучного та цитрусового пектину на рік [1]. Виробництво пектину зосереджено на промислових потужностях всього семи компаній, серед них: СР Kelco, Cargill, DuPont, H\&Fox та декількох менших. У 2019 році до переліку виробників пектину ввійшла українська компанія T.B.Fruit, TM «Galicia», яка стала третім в світі виробником яблучного пектину. Потужність введеного в дію виробництва - 3000 тон на рік. Величина інвестованого у виробництво пектину капіталу становить біля €22 млн. для однієї лінії продуктивністю до 150 т./міс.

Висока вартість існуючих технологій виготовлення пектинових речовин є одним з факторів, що обмежує зростання даного ринку, іншим фактором є складність існуючих технологій виготовлення пектину, їх небезпечність (на окремих етапах використовується спирт) та закритість «клубу виробників».

Технологія виробництва пектину може включати до п’ятнадцяти [2] етапів, кожен з яких сам по собі є достатньо складним технологічним процесом.

В типовому варіанті технологія включає: підготовку пектиновмісної сировини; екстрагування пектину 3 сировини кислотою; фільтрування екстракту, його освітлення та концентрування; осадження з екстракту пектинових речовин спиртами; очистка та сушіння осадженого пектину. 
Мета досліджень. Як будь яка складна технологія, виробництво пектину, має містити можливості для іiі спрощення та удосконалення. Однією з таких можливостей може стати використання інших за принципом діючих впливів на окремих стадіях технологічного процесу. В цьому сенсі технології адресної доставки енергії (АДЕ) можуть бути саме тим фактором, що надасть виробництву пектину достатньо енергії для наступного витку розвитку та удосконалення.

Висока вартість існуючих технологій вимагатиме наявності значних технологічних та/або енергетичних переваг, у альтернатив, що пропонуються на заміну. Розробка та впровадження альтернативної технології можливо ще не на часі, проте в довгостроковому терміні саме інноваційні, енергоефективні та безпечні технології виготовлення пектину матимуть шанс зробити його значно дешевшим і доступним для широкого промислового використання.

Складові елементи таких процесів вже розроблені, тестуються та впроваджуються в інших сферах харчової промисловості. Можливо розробка нової альтернативної технології виготовлення пектиновмісних речовин вже доступна як компіляція існуючих та частково апробованих інноваційних процесів обробки та перетворення харчових компонентів та їх систем?

Колектив науковців кафедри ПОтаЕМ ОНАХТ достатньо довго та успішно працює над технологіями електромагнітного впливу на харчові системи. Ідеологом та науковим керівником даного напряму досліджень $\epsilon$ завідувач кафедри, д.т.н., професор Бурдо О.Г.. Саме його ідеї та наукові передбачення дозволили науковому колективу сформувати «портфоліо» інноваційних технологій використання електромагнітного впливу на типові процеси харчових технологій. Варіативність використання таких технологій досить висока, тому більшість 3 них об'єднані в групу технологій «адресної доставки енергії» (АДЕ), куди входять технології мікрохвильового енергопідведення, сушіння, знезараження, інтенсифікації, екстрагування, випарювання та комбіновані впливи. Більшість $з$ цих технологій описані та вивчені достатньо повно і готові до впровадження. Саме задачі впровадження технологій АДЕ складають основний комплекс наукових завдань науковців кафедри.

3 точки зору використання технологій АДЕ, технологічний процес виробництва пектину має чималий потенціал впровадження. Однією з ділянок де перспективно можливе використання $є$ підготовка пектиновмісної сировини. Особливістю етапу підготовки є необхідність невідкладного та швидкого зневоднення пектиновмісної сировини після іiї вилучення з технологічного процесу. Швидкість процесу висушування відіграє важливу роль через ті обставини, що якість пектиновмісної сировини критично зменшується вже через декілька годин після ії зберігання у вологому вигляді.

В типовому варіанті технологічного процесу використовується конвективні сушіння пектиновмісної сировини, що є значно тривалішим ніж сушіння з використанням АДЕ. В разі використання процесу зневоднення в середовищі мікрохвильового електромагнітного поля, можна високопродуктивно та швидко законсервувати сировину з мінімальною втратою якості.

Результати досліджень. В роботі розглянуто можливість використання технології сушіння оболонки (шкірки) цитрусових комбінованим способом (поєднання мікрохвильового та фільтраційного способів сушіння), отримано результуючі залежності кінетики такого процесу та запропоновано конструкцію сушильного модуля установки з комбінованим способом сушіння. Приклад можливого варіанту такої технологічної лінії приведено на рис. 1. Додаткова функціональність запропонованої конструкції стрічкової мікрохвильової сушарки забезпечується системою фільтраційного сушіння, принцип дії якої полягає в створенні на виході кожної зони мікрохвильового нагріву, ділянки з інтенсивним потоком атмосферного повітря.

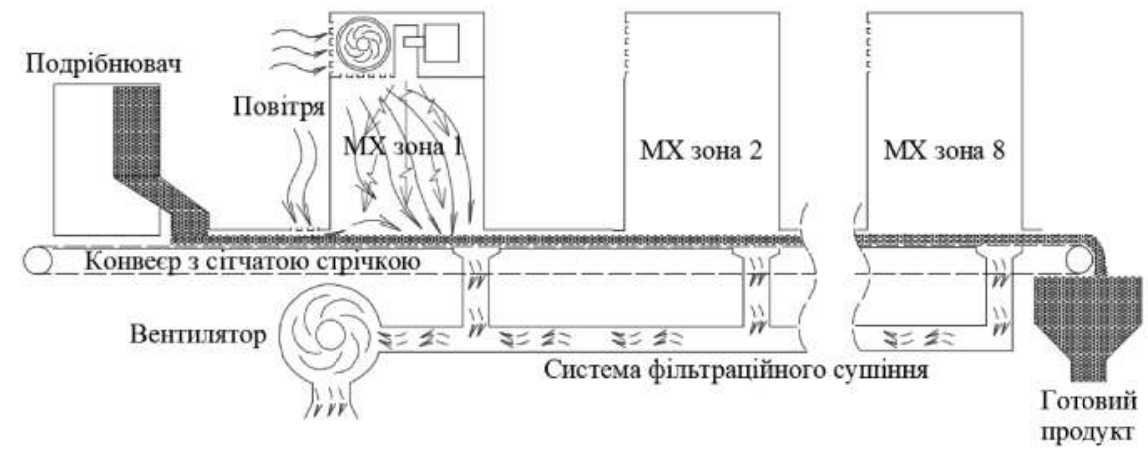

Рис. 1 - Варіант конструкції стрічкової МХ сушарки з комбінованим способом сушіння

При проходженні через таку зону, вологу викинуту на поверхню частинок сировини, внаслідок утворення механодифузійного потоку [3], буде механічно «здуто» 3 поверхні частинок без ії повного випаровування. Експериментальні дослідження режиму механодифузійного видалення вологи підтвердили його ефективність для окремих видів рослинної сировини та дозволили встановити умови виникнення та утримання такого режиму.

Обмеженням для продуктивності та сталості процесу вологовидалення в апараті з комбінованим способом сушіння, може виступати структура поверхні частинок матеріалу. Як показали дослідження високопро- 
дуктивне вилучення вологи простіше організувати для сипучих матеріалів з відносно гладкою поверхнею, 3 розміром частинок в межах 5-10 мм та відносною вологістю від 20 \%. Вплив цих факторів можна пояснити наступним: на поверхні частинок матеріалу з гладкою текстурою поверхні (наприклад, бобів гороху) витіснена механодифузійним потоком волога збиратиметься каплями і значно легше зриватиметься 3 поверхні потоком повітря на ділянці фільтраційного сушіння, одночасно для шару мілкозернистого матеріалу складно створити умови для продування шару з швидкостями потоку повітря в межах 6-8 м/с, що необхідно для продуктивного фільтраційного вологовидалення, а при недостатній початковій вологості матеріалу ініціювання механодифузійного потоку буде ускладнене як швидкоплинністю процесу так і небезпекою перегріву матеріалу.

Необхідною для виникнення явища механодифузії є і наявність розвинутої капілярно-пористої структури матеріалу. Саме при таких умовах, в середовищі високочастотного електромагнітного поля, при достатньому енергетичному впливі (потужності МХ випромінювання), внаслідок об'ємного нагрівання вологи в капілярах частинки матеріалу або в заповнених вологою порах, виникають пухирці пари, надлишковий тиск в яких і є рушійною силою для створення потоків невипареної вологи в тих самих капілярах та порах. Напрям такого потоку визначається градієнтами тиску, температури та вологості в розрізі шарів частинок вологого матеріалу.

Особливістю мікрохвильового нагрівання є його об'ємність, яка і забезпечує формування названих градієнтів в напрямку від вологого центру кожної з частинок до більш сухої поверхні. Рушійна сила процесу вологовидалення буде визначатись сумарним впливом всіх градієнтів, які не є сталими, і змінюються в ході процесу. Так із зменшенням кількості вологи, при постійній величині енергопідведення буде змінюватись співвідношення потужності МХ поля та кількості вологи в частинках, тобто величина енергетичного впливу на процес буде зростати із зменшенням вологи в матеріалі, а так як процес вологовидалення досить швидкий (десятки хвилин), то сталий енергетичний вплив може легко перевищити допустимі межі, що приведе до перегріву і втрати матеріалом частини властивостей.

Таку особливість можна легко врахувати при використанні модульної стрічкової сушильної установки, на зразок зображеної на рис.1. При такій конструкції сумарний енергетичний вплив на матеріал буде визначатись пропорційним впливом кожного з сушильних модулів, що за умови програмного керування їх потужністю дозволить модулювати вплив у відповідності до бажаного режиму сушіння.

В найпростішому варіанті, перші модулі мають забезпечити розігрів вологи в матеріалі достатній для ініціювання ефекту механодифузії, тому їх установлена потужність має бути високою, це $1-3$ модулі, без функції фільтраційного вологовидалення, так як поява вільної вологи на поверхні частинок на даному етапі маловірогідна. Модулі основного процесу, що забезпечують вологовидалення в режимі механодифузії, мають забезпечити достатне енергопідведення для підтримки механодифузійного режиму, величина установленої потужності для них менша, наявність фільтраційного блоку обов'язкова а кількість таких модулів залежатиме від початкової та кінцевої вологості матеріалу яку бажано отримати при одноразовому проходженні потоку. Модулі ділянки досушування можуть мати встановлену потужність в межах 70-50\% від модулів основного процесу, їх кількість залежатиме в першу чергу від необхідності використання режиму «м'якого» сушіння, коли досушування проходитиме при невеликій інтенсивності МХ нагрівання, наявність у модулів досушування фільтраційного блоку також необов'язкова але бажана для уникнення ефекту абсорбування витиснутої вологи самою поверхнею частинки під час транспортування потоку матеріалу між сусідніми модулями.

Приклад залежності кінетики вологовидалення від параметрів комбінованого способу сушіння приведено на рис. 2.
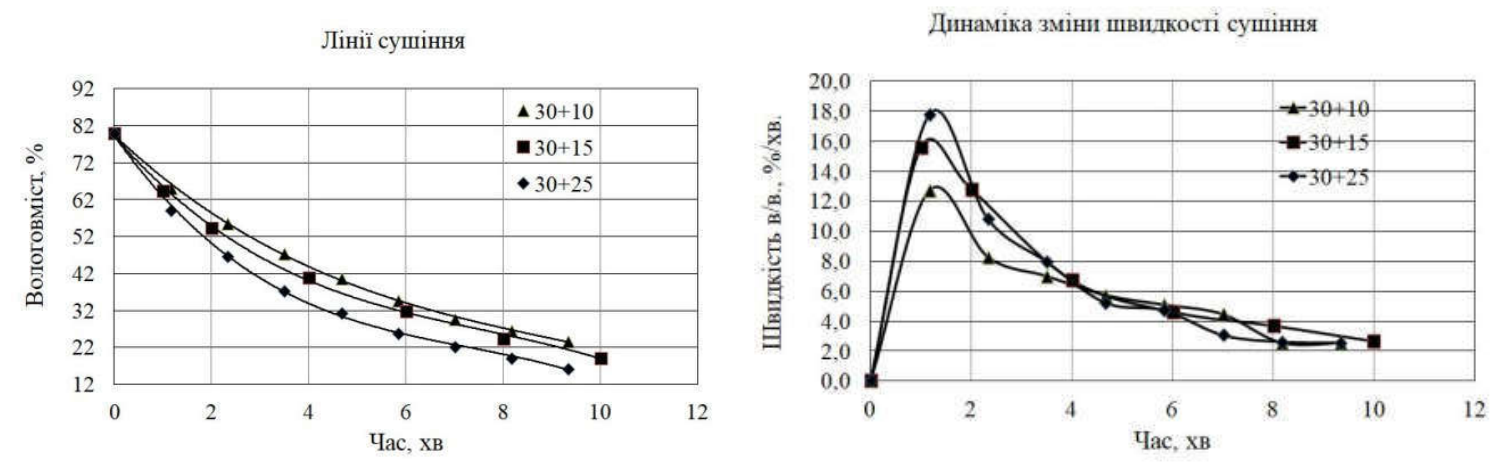

Рис. 2 - Залежність кінетики процесу видалення вологи 3 шкірок цитрусових від тривалості фази фільтраційного сушіння. Легенда, $(30+n)$ : 30-тривалість МХ нагріву, n-тривалість «продувки», с

Отримані результати демонструють високий потенціал комбінованого способу сушіння, зменшення вологості тестового зразка 3 початкових 80 \% вологості до кінцевих 20 \% відбулось внаслідок всього восьми 
циклів обробки. Кожен цикл включав 30 секунд обробки (об'ємного нагрівання) в мікрохвильовому полі та від 10 до 25 секунд продування матеріалу в режимі «фільтраційного сушіння».

Встановлено, що тривалість «продувки» шару матеріалу після його нагрівання в МХ полі має суттєвий вплив на кількість видаленої вологи лише в перших циклах обробки, коли матеріал має значний резерв вологи, яка інтенсивно виводиться на поверхню частинок. В другій половині процесу тривалість «продувки» мало впливає на кінетику вологовидалення. Слід зазначити, що особливістю досліджуємого матеріалу (оболонок цитрусових) є значний вміст легколетучих речовин (ефірних олій), очевидно саме ці речовини забезпечують високі швидкості вологовидалення (12-18 \%/хв..) в першій третині процесу. У попередніх дослідженнях, проведених на інших рослинних матеріалах, типовими швидкостями вологовидалення були 4-10 \%/хв., що також $є$ високим показником. Значна різниця в швидкостях вологовидалення пояснюється як особливостями самих досліджуємих матеріалів, зокрема розвинутості їх капілярно-пористої структури та резервом вологи, так і відповідністю обраного режиму комбінованого впливу на вологу в матеріалі. Складність моделювання такого впливу (як при математичному так і при фізичному моделюванні процесу) пояснюється великою кількістю чинників, що впливають як на процес видалення вологи так і на сталість та повноту досягнутого рівня механодифузійного режиму вологовидалення. Проте навіть неповна оцінка потенціалу даного методу, дозволяє припустити, що промислова сушильна установка з комбінованим способом вологовидалення може мати надвисокі показники як по продуктивності так і по швидкості процесу. Можна припустити, що для поточного рівня розвитку прикладних технологій МХ нагрівання, дослідний зразок сушильної установки 3 комбінованим способом сушіння, для оболонок цитрусових плодів, може мати до 10 сушильних модулів 3 потужністю встановлених генераторів 3-5 кВт в кожному модулі, блоком фільтраційного сушіння для 7-8 модулів основного циклу та етапу досушування і продуктивністю в декілька десятків кілограм на годину, яка залежатиме від характеристик сировини. Продуктивність процесу у промисловому варіанті можна легко нарощувати як паралелізацією потоків так і збільшенням швидкості потоку матеріалу при умові збільшення кількості сушильних модулів в кожному з потоків. Складність керування процесом можливо компенсувати використанням засобів програмного керування та регулювання параметрів роботи кожного 3 сушильних модулів а також використанням комп'ютерно-інтегрованих технологій для організації робочого місця оператора. Для отримання всіх переваг комбінованого способу сушіння необхідно дослідити кінетику процесу вологовидалення для різних типів вологих матеріалів та розробити технологічні карти режимів сушіння для різних цільових процесів, що внаслідок високої складності математичного опису процесу вологовидалення при комбінованому впливі можливо лише в ході експериментального дослідження.

Сушильні апарати з комбінованим способом сушіння є одним з найбільш перспективних напрямів розвитку сушильних технологій. Основними перевагами запропонованого комбінованого способу сушіння та конструкції стрічкової модульної сушильної установки є: висока швидкість вологовидалення, низькі температури процесу (що є важливим для термолабільної рослинної сировини), керованість процесу, екологічна чистота та потенціально-висока енергетична ефективність процесу. Всі ці переваги обумовлені використанням мікрохвильового нагріву в якості системи енергопідведення. Щодо недоліків, можна передбачити відносно високу складність технічного оснащення сушильних МX установок, та деякі обмеження в системі мікрохвильових генераторів. Промислові зразки магнетронів, що використовуються в якості МХ генераторів, на сьогодні мають обмежений ресурс і потужність в межах 1-5 кВт, а для отримання суттєвої для промислового використання потужності електромагнітного поля їх доведеться використовувати у вигляді груп, що також збільшуватиме конструктивну складність промислової сушильної МХ установки. Мікрохвильові генератори високої потужності $(10$ - 100 кВт) є складними для використання в переробній галузі та високовартісними рішеннями.

Перспективні напрями дослідження. Ще одним етапом технологічного процесу виробництва пектину, перспективним для впровадження технологій АДЕ, є процес екстракції пектину спиртом. Процес екстрагування розчинних та слабо розчинних речовин в середовищі електромагнітного поля досліджувався науковцями кафедри в багатьох комбінаціях, зокрема спосіб екстрагування в середовищі МX поля [4], може бути використаний для технології виробництва пектину.

Особливістю технологій АДЕ, при їх використанні для інтенсифікації процесу екстрагування, є можливість використання механодифузійного режиму для інтенсивного видалення екстракційних речовин, що дозволяє в декілька разів (в окремих випадках - в десятки разів) збільшити швидкість процесу екстрагування та повноту вилучення цільового компоненту з первинної сировини.

Саме завдяки механодифузійному ефекту, величина якого може варіюватись в значних межах і залежить від властивостей матеріалу та інтенсивності енергетичного впливу, процес переходу екстрагуємої речовини 3 матеріалу в екстракт може бути значно інтенсивнішим і більш повним, порівняно з традиційним способом екстрагування. Причиною такої суттєвої інтенсифікації $є$ те, що на відміну від традиційного способу, коли інтенсивність процесу визначається переважно взаємодією розчинника та поверхневого шару частинок матеріалу, при ініціюванні механодифузії виникають потужні гідродинамічні потоки з внутрішніх шарів частинок, що значно збільшує продуктивність процесу і зменшує вимоги до площі поверхні екстрагування, а значить і вимоги до підготовки сировини та габаритних показників екстракційного обладнання. Конструкція та загальні принципи функціонування мікрохвильових екстракторів, доцільні для використання в технологічному процесі виробництва пектину описано в роботах [5-6].

Наукові праці, Том 85, випуск 1 
Технологія екстрагування в мікрохвильовому електромагнітному полі може бути значно продуктивнішою по цільовому компоненту (порівняно з типовими способами екстрагування) та ощадливішою у використанні спирту. Можна очікувати, що процес екстрагування буде ефективно реалізовано при температурному режимі, для сировини - в межах $35-50{ }^{\circ} \mathrm{C}$, і значно меншій температурі для розчинника (спирту). Використання температур, нижчих від типових для технології, дозволить збільшити пожеже та вибухобезпечність технології а також скоротити непродуктивні втрати розчинника внаслідок його випаровування.

Використовуючи різні за принципом дії конструкції мікрохвильового екстрактора (можлива реалізація апаратів як безперервної так і періодичної дії), можна виконувати різні технологічні задачі. Так екстрактор безперервної дії може реалізувати процес поточного екстрагування з відносно високим вмістом цільового компоненту та заданою поточною продуктивністю. А при використанні апарату періодичної дії, можливо реалізувати процес екстрагування 3 відносно невисокою поточною продуктивністю, але високим вмістом цільового компоненту, що дозволить значно скоротити та/або спростити наступні етапи виділення пектинової речовини 3 отриманого екстракту.

Кожен 3 типів екстракторів може бути реалізований з заданими конструктивними характеристиками. Практично єдиним реальним обмеженням в конструкції мікрохвильового екстрактора $є$ наявність доступних генераторів мікрохвильового поля (магнетронів) високої потужності.

Перспективною для впровадження технологій АДЕ ділянкою виробництва пектину, можна розглядати i один з кінцевих етапів технологічного процесу - концентрування пектинового екстракту у вакуумних випарних апаратах. Серед розробок кафедри наявні як варіанти конструкції вакуумних випарних апаратів 3 MX енергопідведенням, можливості яких дозволяють отримати на виході практично готовий для використання желеподібний матеріал. Такий варіант організації технологічного процесу дозволить взагалі виключити 3 процесу одну з найбільш енергоємних ділянок - сушіння пектиновмісного концентрованого екстракту в розпилювальній сушарці. Методика розрахунку процесу концентрування розчинів у такому апараті приведена в роботі [7].

Висновки. Попередній аналіз можливостей використання технологій АДЕ для комплексної переробки рослинної сировини, на прикладі технологічного процесу виготовлення пектину, а також результати отримані при сушінні пектинової сировини комбінованим способом, дозволяють стверджувати, що технології адресної доставки енергії, як універсальний спосіб енергопідведення в процесах сушіння, екстрагування та випарювання, можуть радикально змінити як технологічні характеристики цих процесів так і їх енерговитратність, забезпечивши одночасно високу якість отриманого продукту, задану продуктивність та енергетичну ощадливість нової технології.

Значним обмеженням у досягненні промислових рівнів продуктивності для апаратів 3 технологіями АДЕ залишається відносно невисокий рівень потужності електромагнітного поля, що створюється окремо взятим генератором, це обмеження частково компенсується можливістю групового використання генераторів і буде зняте з появою твердотільних генераторів мікрохвильового випромінювання.

\section{References}

1. Gouveia, Teresa I.A., Biernacki, Krzysztof, Castro, Maria C.R., Gonçalves, Maria P., Souza, Hiléia K.S. (2019). A new approach to develop biodegradable films based on thermoplastic pectin. Food Hydrocolloids, 97. 105 - 175. https://doi.org/10.1016/j.foodhyd.2019.105175

2. Stolyarov, V. A. (Ed.). (2006). Novyy spravochnik khimika i tekhnologa [The new handbook of chemist and technologist]. Vol.2: Syr'ye i produkty promyshlennosti organicheskikh i neorganicheskikh veshchestv [Raw materials and industrial products of organic and inorganic substances]. SPb.: Professional (in Russian).

3. Yarovyy, I.I., Ali, V.P. (2020). Initsiyuvannya mekhanodyfuziynoho rezhymu vydalennya volohy v protsesakh sushinnya roslynnoyi syrovyny [Initiation of a mechanodiffusion mode for removing moisture in the drying processes of vegetable raw materials]. Proceedings of scientific-practical conference "Enerhiya. Biznes. Komfort" (p.p. 12-77) Одеса (in Ukrainian). URL: https://www.onaft.edu.ua/download/konfi/2020/Collection-of-abstracts-EBC2020.pdf

4. Burdo, O. H., Terziyev, S. H., \& Ruzhytska, N. V. (2013). Uzahal'nennya eksperymental'nykh doslidzhen' ekstrahuvannya shlamu kavy [Generalization of experimental studies of coffee sludge extraction]. Scientific works, 44(2). 334-337 (in Ukrainian).

5. Terziyev, S., Levtrinskaya, Yu., \& Burdo, O. (2017). Sovershenstvovaniye teplotekhnologiy proizvodstva kofe [Improvement of heat technologies for coffee production]. Scientific Works, 47. (in Russian). https://doi.org/10.15673/swonaft.v1i47.405

6. Burdo, O., Burdo, A., Al'khuri, Yu., \& Sirotyuk, I. (2016). Massoperenos pri ekstragirovanii iz lechebnogo rastitel'nogo syr'ya v elektromagnitnom pole [Mass transfer in extraction from medicinal vegetable material in electromagnetic field]. Scientific Works, $80(1) . \quad 65 \quad-\quad 74 \quad$ (in Russian). https://doi.org/10.15673/swonaft.v80i1.224

7. Ruzhytska, N., Riznychenko, T. \& Voytenko, O. (2018). Metodyka rozrakhunku protsesu kontsentruvannya kharchovykh rozchyniv ta ekstraktiv u mikrokhvyl'ovomu vakuum-vyparnomu aparati [Method of calculation 
food solutions and extracts concentration process in microwave vacuum evaporator]. Scientific Works, 82(1). 139 - 143 (in Ukrainian). https://doi.org/10.15673/swonaft.v82i1.1020

\title{
COMPREHENSIVE PROCESSING OF RAW MATERIALS USING TECHNOLOGIES OF ADDRESSED ENERGY DELIVERY IN THE PRO- DUCTION OF PECTINS
}

\author{
Yarovy I.I., Ph.D., Ali V.P., graduate student \\ Odessa National Academy of Food Technologies
}

Possibilities of using technologies of targeted energy delivery (ADE) in the processes of complex processing of raw materials of plant origin on the example of a set of technological processes characteristic for the production of pectin are considered. The relevance of pectin production processes for modern industry and promising areas of pectin use are shown. Examples of realization of technologies of pectin production by domestic and foreign producers are given, and the approximate estimation of cost and complexity of pectin production is resulted.

As an option to improve and reduce the cost of pectin production technology, the use of ADE technologies for the main technological operations of pectin production is proposed: drying of pectin-containing raw materials, extraction of pectin-containing substances, evaporation of pectin-containing extract.For the process of drying pectin-containing raw materials, the results of an experimental study of the kinetics of the process of moisture removal from the skin of citrus fruits, using a combined method of drying - microwave power supply and filtration removal of moisture. Substantiation for the use of such a combination of drying technologies and the influence of the mechanodiffusion effect on the final moisture removal productivity by the specified combined drying method are offered. The general design of a belt, modular drying unit with a combined method of drying bulk vegetable raw materials is described.

The evaluation of the results obtained during the study of the kinetics of the drying process of pectin-containing raw materials and the overall potential of ADE technology for the processes of high-speed low-temperature drying of thermolabile materials is given. The way for introduction of ADE technologies in other technological sites of pectin production is offered. In particular, reference is made to innovative extraction processes in the environment of the ultrahigh frequency electromagnetic field and summarizes the potential advantages and disadvantages of using similar technologies in the production of pectin. The use of technology of evaporation of solutions in vacuum evaporators with the use of microwave power supply for a similar technological operation in the manufacture of pectin is proposed.

Keywords: pectin, microwave, electro-magnetic field, extraction, evaporation.

\section{Список використаної літератури}

1. Gouveia, Teresa I.A., Biernacki, Krzysztof, Castro, Maria C.R., Gonçalves, Maria P., Souza, Hiléia K.S. A new approach to develop biodegradable films based on thermoplastic pectin, Food Hydrocolloids, 2019, Volume 97, P. 105 - 175. https://doi.org/10.1016/j.foodhyd.2019.105175

2. Новый справочник химика и технолога: справочное издание / ред. В. А. Столярова. Ч. 2 : Сырье и продукты промышленности органических и неорганических веществ. СПб. : Профессионал, 2006. 1142 с.

3. Яровий I.I., Алі В.П., Ініціювання механодифузійного режиму видалення вологи в процесах сушіння рослинної сировини. Енергія. Бізнес. Комфорт: матеріали науково-практичної конференції (26листопада 2020p.). Одеса : OHAXT, 2020. C. 12-77. - URL: https://www.onaft.edu.ua/download/konfi/2020/Collection-of-abstracts-EBC2020.pdf

4. Бурдо О. Г., Терзієв, С. Г., Ружицька, Н. В. Узагальнення експериментальних досліджень екстрагування шламу кави. Наукові праці, 2013. Вип. 44(2). С. 334-337.

5. Терзиев, С., Левтринская, Ю., \& Бурдо, С. (2017). Совершенствование теплотехнологий производства кофе. Scientific Works, 47. https://doi.org/10.15673/swonaft.v1i47.405

6. Бурдо, О., Бурдо, А., Альхури, Ю., \& Сиротюк, И. (2016). Массоперенос при экстрагировании из лечебного растительного сырья в электромагнитном поле. Scientific Works, 80(1). C. 65 - 74. https://doi.org/10.15673/swonaft.v80i1.224

7. Ружицька, Н., Різниченко, Т., \& Войтенко, О. (2018). Методика розрахунку процесу концентрування харчових розчинів та екстрактів у мікрохвильовому вакуум-випарному апараті. Scientific Works, 82(1). C. 139 - 143. https://doi.org/10.15673/swonaft.v82i1.1020

Отримано в редакцію 01.04.2021

Прийнято до друку 06.07.2021
Received 01.04.2021

Approved 06.07.2021 